\title{
A new calcium binding glycoprotein family constitutes a major diatom cell wall component
}

\section{Nils Kröger ${ }^{1}$, Christian Bergsdorf and Manfred Sumper}

\author{
Lehrstuhl für Biochemie I, Universität Regensburg, 93040 Regensburg, \\ Germany \\ ${ }^{1}$ Corresponding author \\ Communicated by W.Tanner
}

Diatoms possess silica-based cell walls with speciesspecific structures and ornamentations. Silica deposition in diatoms offers a model to study the processes involved in biomineralization. A new wall is produced in a specialized vesicle (silica deposition vesicle, SDV) and secreted. Thus proteins involved in wall biogenesis may remain associated with the mature cell wall. Here it is demonstrated that EDTA treatment removes most of the proteins present in mature cell walls of the marine diatom Cylindrotheca fusiformis. A main fraction consists of four related glycoproteins with a molecular mass of approximately $75 \mathrm{kDa}$. These glycoproteins were purified to homogeneity. They consist of repeats of $\mathrm{Ca}^{2+}$ binding domains separated by polypeptide stretches containing hydroxyproline. The proteins in the EDTA extract aggregate and precipitate in the presence of $\mathrm{Ca}^{2+}$. Immunological studies detected related proteins in the cell wall of the freshwater diatom Navicula pelliculosa, indicating that these proteins represent a new family of proteins that are involved in the biogenesis of diatom cell walls.

Key words: calcium binding glycoprotein/Cylindrotheca fusiformis/diatom cell wall/silica deposition vesicle

\section{Introduction}

Diatoms are encased by two siliceous valves which together, along with organic components, comprise the cell wall of these organisms. The outstanding feature of diatoms is the intriguing species-specific design and ornamentation of their silica-based cell walls. The two parts of the cell wall are termed the hypotheca and epitheca, which overlap. Each theca is tightly enclosed by a layer of non-siliceous material (organic casing; Volcani, 1978) and is composed of a valve and several silica strips (girdle bands) which run laterally along the long axis of the cell. It is the girdle band region in which the thecae overlap. The schematic drawing (Figure 1A) shows a cross section through a typical diatom cell wall. In the case of the marine diatom Cylindrotheca fusiformis used in this study, the valve area between the raphe (a specialized region including a longitudinal slit through the valve) and the girdle bands is totally unsilicified, thus consisting of purely organic material (Figure 1B).

New valves are produced after cell division and cyto- kinesis of the mother protoplast. The resulting daughter protoplasts are trapped within the cell wall of the mother cell. If silicate is available, each daughter protoplast forms a new valve. These are formed within the protoplast in a specialized organelle, the silica deposition vesicle (SDV; Volcani, 1981). The SDV membrane (silicalemma) lies closely beneath the plasma membrane and extends during the process of silicate deposition (Volcani, 1981). Finally, the SDV spans the whole area beneath the plasma membrane, containing a new valve. The new valve is transported out of the protoplast and the daughter cells separate, each possessing a maternal epitheca and a newly formed hypotheca.

Up to now, very little has been known about the membrane processes and the proteins involved in valve

A

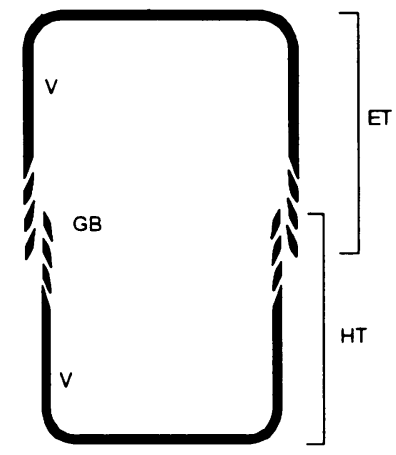

B
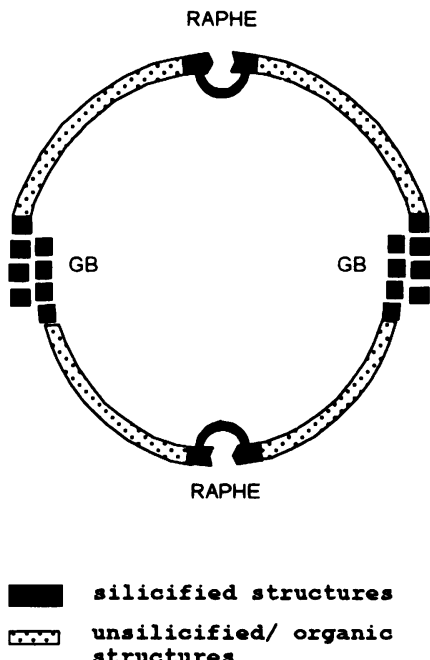

Fig. 1. Schematic drawing of a diatom cell wall. A diatom cell wall in section (A), consisting of two thecae: an epitheca (ET) and a hypotheca (HT). The thecae consist of the valve (V) and the girdle bands (GB). (B) A cross section through a cell wall of $C$.fusiformis. For a detailed description of the diatom cell wall structure see Volcani (1981) and Reimann et al. (1965). 


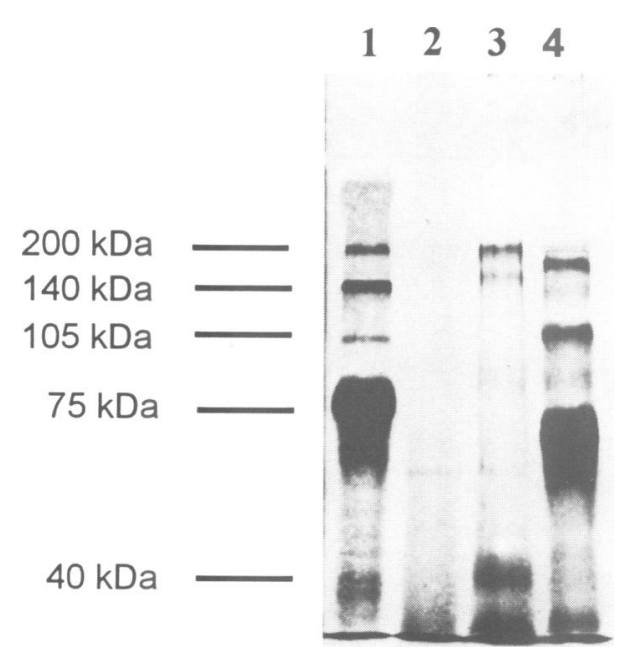

Fig. 2. Sequential extraction of $C$.fusiformis cell walls. Isolated cell walls of $10^{7}$ cells were subjected to successive treatment with EDTA (lane 1), SDS (lane 2), HF (lane 3) or HF and EDTA (lane 4). The complete material of each extract was subjected to $8 \%$ SDS-PAGE and silver stained.

formation. The species-specific architecture of the silica structures clearly indicates a genetic determination. It is possible that proteins found in the mature diatom cell wall are components (and structural determinants) of the valveforming machinery within the SDV. Although amino acid analysis of purified diatom valves has revealed the presence of proteins (Hecky et al., 1973), no diatom cell wall protein has been isolated so far.

Here we present the protein composition of the cell wall of the diatom C.fusiformis. As mentioned above, the unique feature of this particular valve is an unsilicified area between the lateral girdle bands and the silicified raphe region. The silica parts of the cell wall are tightly enclosed by organic material which seems to be continuous with the organic material in the unsilicified wall area (Reimann et al., 1965). Thus, C.fusiformis offers the possibility of distinguishing between silica-associated and silica-independent organic cell wall components.

We have characterized a set of related $C$.fusiformis cell wall glycoproteins. These glycoproteins exhibit unique structural features and biochemical properties and are members of a new protein family found in diatoms.

\section{Results}

\section{Sequential extraction of C.fusiformis cell walls}

Diatom cells were completely lysed by vigorous shaking with glass beads. Due to the high density of biogenic silica $(r=2.1 \mathrm{~kg} / \mathrm{l})$, the diatom cell wall can be easily removed from a cell lysate by low speed centrifugation. Isolated cell walls were sequentially extracted with EDTA, followed by $1 \%$ SDS at $95^{\circ} \mathrm{C}$ and finally treated with liquid $\mathrm{HF}$ to dissolve the silica. Extracts were analysed for the presence of proteins by SDS-PAGE and subsequent silver staining (Figure 2). On lanes loaded with the SDS fractions, almost no bands are visible, indicating the virtual absence of adhering membranes (Figure 2, lane 2). The majority of cell wall proteins appear in the EDTA extract, with major bands at 200,140,105 and $75 \mathrm{kDa}$ (Figure 2, lane 1). The HF extract reveals two high

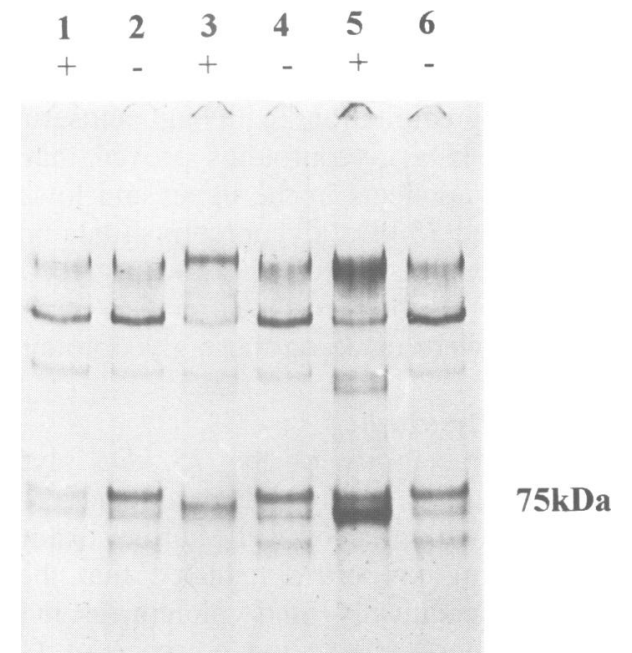

Fig. 3. ${ }^{14} \mathrm{C}$-labelling of EDTA-extractable cell wall components. Synchronized and silicon-starved cells were labelled with $\mathrm{NaH}^{14} \mathrm{CO}_{3}$ for $2 \mathrm{~h}$ at various times after addition of silicate as described in the text. Equal fractions of EDTA-extracted cell wall material were analysed by $8 \%$ SDS-PAGE and subsequent autoradiography. - , silicon starved cells; + , silicon-starved cells that were resupplied with silicate. Lanes 1 and 2, labelling period 2-4 h after silicate addition to $+\mathrm{Si}$ cells; lanes 3 and $4,4-6 \mathrm{~h}$; lanes 5 and 6,6-8 h.

molecular mass components at 200 and $155 \mathrm{kDa}$, as well as two low molecular mass bands at 30 and $40 \mathrm{kDa}$ (Figure 2, lane 4). For comparison of the proteins in EDTA and HF extracts, the EDTA fraction was in addition treated with HF. Each of the proteins in the EDTA extract showed a mobility shift following this treatment, demonstrating glycosylation, since HF specifically cleaves $O$-glycosidic bonds (Mort and Lamport, 1977). As a result, all of the polypeptides in the EDTA and HF extracts migrated with different mobilities on SDS-PAGE, suggesting that the polypeptides of both extracts are different.

\section{${ }^{14} \mathrm{C}$-Labelling of cell wall components during valve formation}

If a diatom culture is incubated in growth medium without any added silicon, cells stop growing within $12 \mathrm{~h}$. The synchronous formation of new hyothecae can be induced by resupplying the medium with silicate (Paul and Volcani, 1976). Within $8 \mathrm{~h}$ after addition of silicate, the daughter cells separate, each provided with a complete wall. Changes in composition of the cell wall during valve formation were followed by ${ }^{14} \mathrm{C}$-labelling of silicateinduced cells.

A silicon-starved culture of $C$.fusiformis was divided into two aliquots. One culture was left under silicon starvation ( $-\mathrm{Si}$ cells), the other was resupplied with silicate ( + Si cells). At $2 \mathrm{~h}$ intervals an equal amount of cells was removed from each culture and pulse-labelled for $2 \mathrm{~h}$ by adding $\mathrm{NaH}^{14} \mathrm{CO}_{3}$. Subsequently, cell walls were prepared and extracted with EDTA. The EDTA extract was analysed by SDS-PAGE and autoradiography (Figure 3).

The $-\mathrm{Si}$ cells exhibit constant labelling in the upper $75 \mathrm{kDa}$ region, but only weak labelling in the lower 
$75 \mathrm{kDa}$ region. The label in the lower $75 \mathrm{kDa}$ region markedly increases during valve formation of the $+\mathrm{Si}$ cells. Immunoprecipitation with an antiserum raised against the $75 \mathrm{kDa}$ glycoproteins proved that both the ${ }^{14} \mathrm{C}$-labelled components in the upper and lower $75 \mathrm{kDa}$ region are indeed $75 \mathrm{kDa}$ glycoproteins (data not shown).

Since the accumulation of the $75 \mathrm{kDa}$ glycoproteins in the cell wall corresponds to the formation of new valves, further studies were made on these glycoproteins.

\section{Calcium affinity studies}

The EDTA-extractability of the $75 \mathrm{kDa}$ glycoproteins suggests divalent cation-mediated association of these glycoproteins within the cell wall. Further examination of their ion binding properties revealed that the $75 \mathrm{kDa}$ glycoproteins specifically bind calcium, as indicated by independent criteria: (i) in the presence of $\mathrm{CaCl}_{2}$ they showed a mobility shift on SDS-PAGE that did not occur in the presence of other divalent cations (Figure 4A); (ii) the $75 \mathrm{kDa}$ glycoproteins blotted onto nitrocellulose membrane bound ${ }^{45} \mathrm{Ca}^{2+}$ despite the presence of a $10^{6}$ molar excess of $\mathrm{Mg}^{2+}$ (Figure 4B, lane 3). The observed intensity of ${ }^{45} \mathrm{Ca}^{2+}$ labelling of the $75 \mathrm{kDa}$ glycoproteins was comparable with that of calmodulin (Figure 4B, lanes 1, 3 and 4), whereas equal amounts of BSA and transferrin (Figure $4 \mathrm{~B}$, lane 5) did not bind ${ }^{45} \mathrm{Ca}^{2+}$ at all under the same conditions. Calcium binding activity is observed in whole cell lysates of C.fusiformis (Figure 4B, lane 2), with the most intense signal residing in the $75 \mathrm{kDa}$ region. There are only two additional ${ }^{45} \mathrm{Ca}^{2+}$ binding components detectable in the whole cell lysate, which correspond to the $200 \mathrm{kDa}$ and $140 \mathrm{kDa}$ glycoproteins of the EDTA cell wall extract (Figure 4B, lane 1).

Both the $\mathrm{Ca}^{2+}$-specific mobility shift in SDS-PAGE and ${ }^{45} \mathrm{Ca}^{2+}$ binding on nitrocellulose membranes are diagnostic of $\mathrm{Ca}^{2+}$ binding proteins (Cartaud et al., 1980; Maruyama et al., 1984).

The components present in the EDTA cell wall extract form a precipitate in the presence of $\mathrm{Ca}^{2+}$ (Figure $4 \mathrm{C}$, lanes 2 and 5). Precipitation does not occur in the presence of other divalent cations (Figure 4C, lanes 3 and 4). The purified $75 \mathrm{kDa}$ glycoproteins no longer precipitate in the presence of $\mathrm{Ca}^{2+}$ (Figure 4A, lane 2), indicating that one or more additional components are involved in this reaction.

\section{Analysis of neutral sugars}

Synchronized and silicon-starved cells of $C$.fusiformis were pulse-labelled for $2 \mathrm{~h}$ with $\mathrm{H}^{14} \mathrm{CO}_{3}{ }^{-} 6 \mathrm{~h}$ after the addition of silicate. The EDTA extract of cell walls was subjected to SDS-PAGE and the $75 \mathrm{kDa}$ region was excised from the gel and eluted. Neutral sugars were analysed as their alditol acetates by radio gas chromatography.

Rhamnose, galactose, xylose, glucose, mannose and an unidentified sugar component in the ratio 5:4:4:2:1:4 were found to constitute the neutral sugar components of the $75 \mathrm{kDa}$ glycoproteins.

\section{Purification of the $75 \mathrm{kDa}$ glycoproteins}

An EDTA extract of cell walls was subjected to gel filtration through a Superdex 200 column. The fractions containing the $75 \mathrm{kDa}$ glycoproteins were then loaded on a MonoQ column at $\mathrm{pH} 5$ and eluted with a linear $\mathrm{NaCl}$
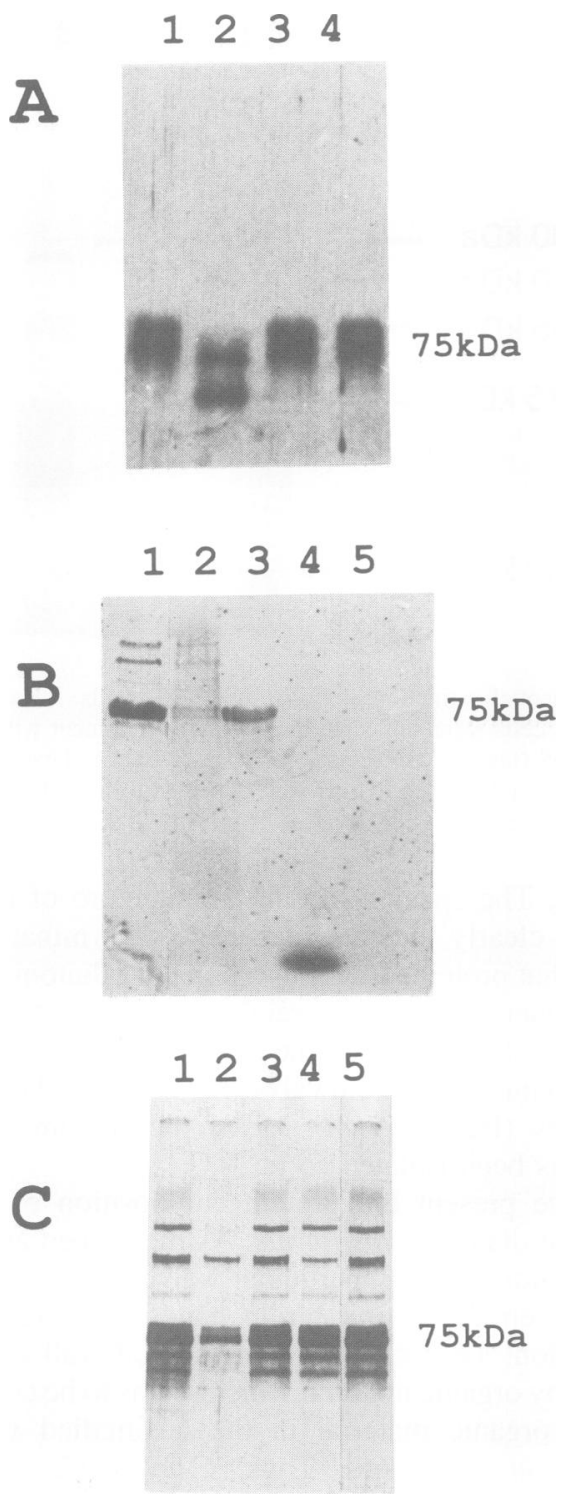

Fig. 4. $\mathrm{Ca}^{2+}$ binding assays. (A) $\mathrm{Ca}^{2+}$-dependent mobility-shift of $75 \mathrm{kDa}$ glycoproteins on SDS-PAGE. $75 \mathrm{kDa}$ glycoproteins $(1 \mu \mathrm{g})$ were incubated in the presence of $10 \mathrm{mM}$ solutions of the indicated salt, subjected to $8 \%$ SDS-PAGE and silver stained. SDS-PAGE time was twice as long compared with normal SDS-PAGE conditions. Lane 1, EDTA, pH 8; lane 2, $\mathrm{CaCl}_{2}$; lane $3, \mathrm{MgCl}_{2}$; lane $4, \mathrm{ZnCl}_{2}$. (B) Autoradiogram of a nitrocellulose membrane that was overlaid with ${ }^{45} \mathrm{Ca}^{2+}$-containing buffer at $\mathrm{pH} 6$ and subsequently washed. Lane 1 , EDTA cell wall extract ( $10 \mu \mathrm{g}$ protein); lane 2 , whole cell lysate (50 $\mu \mathrm{g}$ protein); lane $3,5 \mu \mathrm{g} 75 \mathrm{kDa}$ glycoproteins; lane $4,5 \mu \mathrm{g}$ calmodulin; lane $5,5 \mu \mathrm{g}$ BSA $(66 \mathrm{kDa})+5 \mu \mathrm{g}$ transferrin $(78 \mathrm{kDa})$. $12 \%$ SDS-PAGE. (C) $\mathrm{Ca}^{2+}$-dependent precipitation of EDTAextractable cell wall components. To EDTA cell wall extracts, each containing $2 \mu \mathrm{g}$ protein in $10 \mathrm{mM}$ Tris $-\mathrm{HCl}, \mathrm{pH} 7.5,500 \mathrm{mM} \mathrm{NaCl}$ buffer, the indicated salt was added to a final concentration of $10 \mathrm{mM}$. After $30 \mathrm{~min}$ incubation at $20^{\circ} \mathrm{C}$ each sample was centrifuged for 5 min at $14000 \mathrm{~g}$. Supernatants (lanes 1-4) and the pellet (lane 5) were subjected to $8 \%$ SDS-PAGE and silver stained. Lane 1 , no salt added; lanes 2 and $5, \mathrm{CaCl}_{2}$; lane $3, \mathrm{MgCl}_{2}$; lane $4, \mathrm{ZnCl}_{2}$.

gradient. The elution profile (Figure $5 \mathrm{~A}$ ) reveals separation of the $75 \mathrm{kDa}$ glycoproteins into three fractions: $75 \mathrm{~K} \alpha$ (peak 1), $75 \mathrm{~K} \beta$ (peak 2) and $75 \mathrm{~K} \gamma$ (peak 3) and $75 \mathrm{~K} \delta$ (peak 3). Whereas $75 \mathrm{~K} \alpha, 75 \mathrm{~K} \beta$ and $75 \mathrm{~K} \delta$ show about the same mobilities on SDS-PAGE, $75 \mathrm{~K} \gamma$ has a significantly lower mobility (Figure 5B). This is due to differences in 


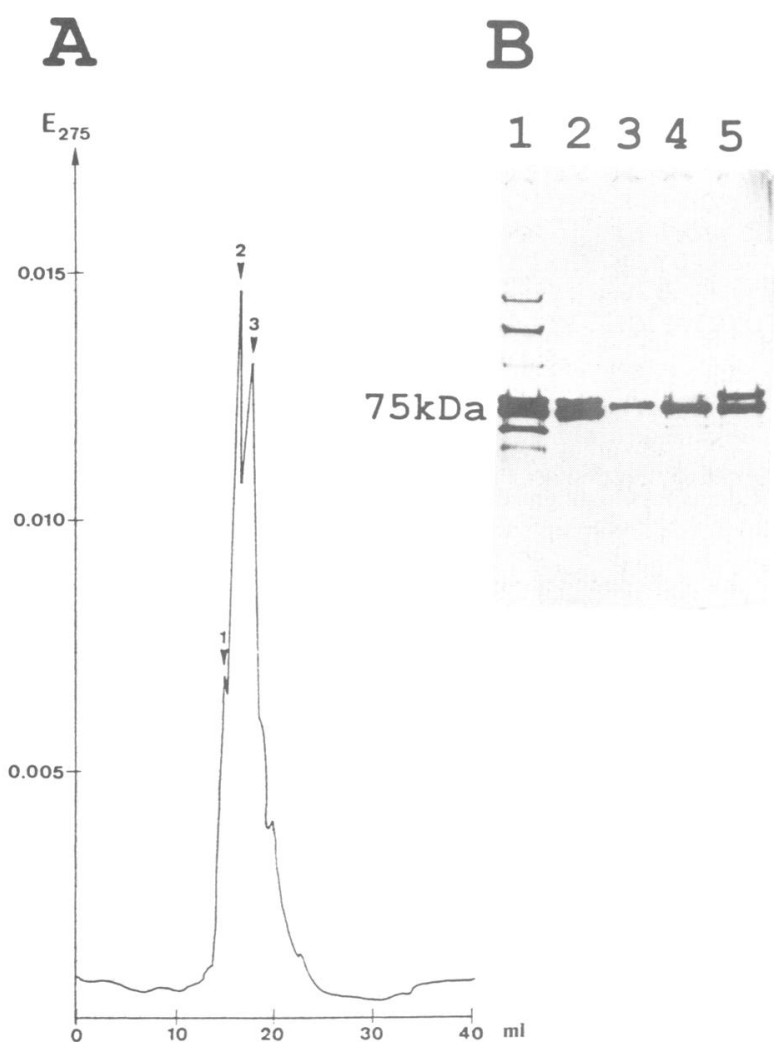

Fig. 5. Purification of $75 \mathrm{kDa}$ glycoproteins. (A) Chromatography on MonoQ run at $\mathrm{pH} 5$. Approximately $500 \mu \mathrm{g}$ of $75 \mathrm{kDa}$ glycoproteins were loaded onto the column. Elution was performed with a linear $\mathrm{NaCl}$ gradient $(0-500 \mathrm{mM} \mathrm{NaCl}$ over $30 \mathrm{~min}$, flow rate $1 \mathrm{ml} / \mathrm{min}$, $\mathrm{E}_{275}=$ extinction at $275 \mathrm{~nm}$ ). (B) Silver stained SDS-PAGE showing the purification steps. Equal portions of $75 \mathrm{kDa}$ glycoproteincontaining fractions were loaded onto the gel. Lane 1, EDTA extract of purified cell walls; lane 2, 'fraction $60-65 \mathrm{ml}$ ' of Superdex 200 eluate; lane 3, peak 1 of MonoQ eluate (five times concentrated compared with all other fractions); lane 4, peak 2 of MonoQ eluate; lane 5, peak 3 of MonoQ eluate. 8\% SDS-PAGE.

the polypeptide backbone of the $75 \mathrm{~K} \gamma$ glycoprotein, since deglycosylated $75 \mathrm{~K} \gamma$ has an apparent molecular weight of $68 \mathrm{kDa}$ in SDS-PAGE, whereas $75 \mathrm{~K} \alpha, 75 \mathrm{~K} \beta$ and $75 \mathrm{~K} \delta$ migrate at $65 \mathrm{kDa}$ (data not shown). Final purification of the $75 \mathrm{kDa}$ glycoproteins was achieved by native PAGE of the corresponding MonoQ eluates, the bands of the individual glycoproteins being excised and subsequently eluted into buffer.

\section{Protein chemistry studies}

The N-termini of the glycoproteins $75 \mathrm{~K} \beta, 75 \mathrm{~K} \gamma$ and $75 \mathrm{~K} \delta$ were analysed by automated Edman degradation. While the $\mathrm{N}$-terminus of $75 \mathrm{~K} \gamma$ was blocked, $75 \mathrm{~K} \beta$ and $75 \mathrm{~K} \delta$ showed the same $\mathrm{N}$-terminal sequence:

\section{K $\beta$ : X A E I P I V K V}

75K $\delta$ : X A E I P I V K

The purified glycoproteins $75 \mathrm{~K} \gamma, 75 \mathrm{~K} \delta$ and $75 \mathrm{~K} \beta$ were separately digested with endoproteinase LysC and the peptides separated by reversed phase HPLC. The individual $75 \mathrm{kDa}$ species showed very similar peptide patterns; in the case of $75 \mathrm{~K} \delta$ and $75 \mathrm{~K} \beta$ they were virtually identical. The material from well-separated peaks were subjected to amino acid sequence analysis on an automated
Table I. Peptide sequences of $75 \mathrm{kDa}$ glycoproteins

\begin{tabular}{|c|c|}
\hline Peptide & Amino acid sequence \\
\hline \multicolumn{2}{|c|}{ LysC peptides of $75 \mathrm{~K} \beta$} \\
\hline Ll & V GEEPATPLGRXEGDX DK \\
\hline L2 & $X F Q R D G G E S \vee P G X S G G S X D$ \\
\hline L3 & XF Q R T E NFK \\
\hline L4 & Q A E I P I V K \\
\hline L5 & X S D X G S G L K \\
\hline L6 & E N $P$ S X $P P \times X P$ A $P$ A X T T T P $P X L$ \\
\hline \multicolumn{2}{|c|}{ LysC peptides of $75 \mathrm{~K} \gamma$} \\
\hline L7 & $\begin{array}{l}\text { V G E E P A T P L G R X E G D X X K } \\
\text { (100\% identity to L1) }\end{array}$ \\
\hline L8 & M G E E P A T P L G X X E (85\% identity to L1) \\
\hline L9 & X Y Q R T E N F K (88\% identity to L3) \\
\hline L10 & X S D C G S G L K ( $88 \%$ identity to L4) \\
\hline \multicolumn{2}{|c|}{ Tryptic peptides of $75 \mathrm{kDa}$ glycoprotein mixture } \\
\hline $\mathrm{T} 1$ & V G A N P G V P L E R \\
\hline $\mathrm{T} 2$ & A T D Y D F P L G L X E G D C D D \\
\hline $\mathrm{T} 3$ & A V P GXSGGAQDSSFF Y X V R \\
\hline T4 & M G E E P A T P L G X \\
\hline T5 & V G E E P A T P L G R \\
\hline T6 & X D Y X I P K \\
\hline $\mathrm{T} 7$ & T D Y X I V K \\
\hline
\end{tabular}

gas phase sequencer. The amino acid sequence data obtained are summarized in Table I. The peptides of $75 \mathrm{~K} \beta$ and $75 \mathrm{~K} \gamma$ are strikingly homologous, or even identical to each other. Remarkably, peptide L6 contains hydroxyproline, a well known constituent of cell wall proteins of algae and higher plants (Showalter, 1993).

The sequence information obtained from the LysC peptides of the purified $75 \mathrm{kDa}$ glycoproteins did not allow us to design appropriate oligonucleotide primers for PCR. Therefore, we performed a tryptic digestion of the $75 \mathrm{kDa}$ glycoprotein mixture. Separation and sequencing of the resulting peptides was as described above. The sequences of the tryptic peptides are summarized in Table I.

\section{Amplification of a cDNA sequence by polymerase chain reaction (PCR)}

The amino acid sequence of the tryptic peptide T3 (Table I) was used to synthesize degenerated oligonucleotide primers. The sense primer 5'-GCN GTN CCN GG-3' was designed from amino acid positions 1-4. The antisense primer 5'-GTA RTC RAA RAA-3' was designed from amino acid positions 14-17. The latter primer was used to reverse transcribe total RNA of C.fusiformis. The resulting cDNA was amplified by PCR using both the sense and antisense primers. Thirty cycles of amplification produced a cDNA fragment of $51 \mathrm{bp}$ in length, which was cloned and sequenced. The deduced amino acid sequence matched the sequence of peptide T3, with cysteine at amino acid position 5. Sequence information from this $51 \mathrm{bp}$ fragment was used to collect the complete cDNA sequence by the RACE-PCR technique (Frohman et al., 1988). Cloning of the PCR product covering the $5^{\prime}$ region revealed an open reading frame matching the $\mathrm{N}$ terminal sequences of $75 \mathrm{~K} \beta$ and $75 \mathrm{~K} \delta$. The PCR product covering the $3^{\prime}$ region was $1375 \mathrm{bp}$ in length, revealing an open reading frame that encoded 12 out of the 17 


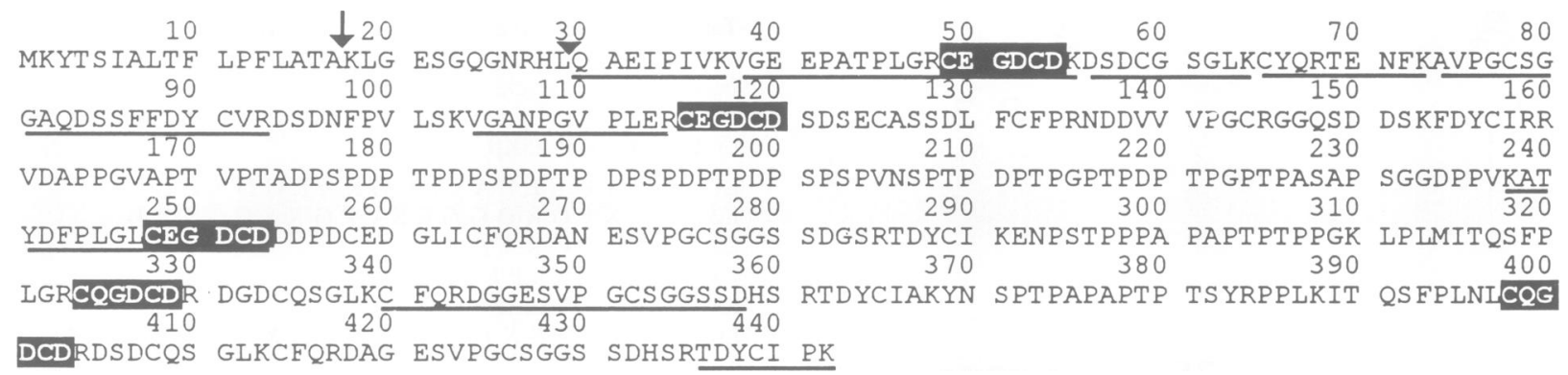

Fig. 6. Amino acid sequence of $\mathrm{p} 75 \mathrm{~K}$. The putative signal peptidase cleavage side is marked with an arrow. The start of the mature polypeptide as derived from $\mathrm{N}$-terminal amino acid sequence analysis is marked with an arrowhead. Amino acid sequences derived from isolated peptides are underlined. The hexapeptide sequence CE/QGDCD occurring once in each ACR domain is highlighted.

peptides obtained by proteolytic digestion of the $75 \mathrm{kDa}$ glycoproteins (Table I). In order to rule out the possibility that the products of 5' RACE-PCR and 3' RACE-PCR were derived from different, but highly homologous genes, we performed three nested 5' RACE-PCR reactions using primers that correspond to sequences near the $3^{\prime}$ end of the gene. The products of the second and third PCR reactions were cloned and sequenced. Both match the sequence of the previously cloned $5^{\prime}$ end. As a result, the products of the RACE-PCR reactions in both directions were derived from the same cDNA molecule, which we denoted as $75 \mathrm{KcDNA}$.

\section{Primary structure of the 75KcDNA-encoded polypeptide (p75K)}

75KcDNA reveals an open reading frame coding for 442 amino acids (Figure 6). Amino acid positions 30-38 are identical to the $\mathrm{N}$-termini of $75 \mathrm{~K} \beta$ and $75 \mathrm{~K} \delta$, so that amino acids 1-29 are likely to act as a leader peptide(s) necessary to direct the protein into the cell wall. The first 17 amino acids of this pre-sequence represent a typical signal sequence allowing for the import of a nascent polypeptide into the lumen of the endoplasmatic reticulum. It contains a positively charged $\mathrm{N}$-terminal end $(\mathrm{K}$ at amino acid position 2), followed by a stretch of uncharged and hydrophobic amino acids (amino acid positions 314). The tripeptide sequence A T A (amino acid positions 15-17) shows the typical motif for a signal peptide cleavage site (Perlman and Halvorsson, 1983). Consequently, amino acids 18-29 are likely to encode an additional, as yet unknown, pre-sequence. It contains three charged residues, a histidine residue and is mainly hydrophilic.

The main feature of the 75KcDNA-encoded polypeptide (p75K) is its highly repetitive structure. The hexapeptide motif CE/QGDCD occurs five times and is evenly distributed within the polypeptide. In each case the hexapeptide is embedded in a domain consisting of 53-56 amino acid residues that is rich in aspartate, glutamate and cysteine. All five domains [1 (38-93) to 5 (389-442)] share a high degree of sequence identity (43-87\%) to each other (see Figure 7A). With respect to these features, we named them acidic cysteine-rich domains (ACR domains). ACR domains 2 (104-159) and 3 (239-291), ACR domains 3 and 4 (315-368) and ACR domains 4 and 5 (389-442) are connected by polyproline stretches containing proline in almost every other amino acid position. Figure 7B shows a schematic diagram of the polypeptide structure. $\mathrm{p} 75 \mathrm{~K}$ is very acidic, with a predicted $\mathrm{pI}$ of 4 . This property is in good agreement with the nature of the $75 \mathrm{kDa}$ glycoproteins, since these firmly bind to MonoQ anion exchange matrix at $\mathrm{pH} 5$. The deduced polypeptide includes all peptides obtained from the $75 \mathrm{kDa}$ glycoprotein fractions except peptides T4, T7, L3, L6 and L8. However, there are sequences in p75K highly homologous to these missing peptides. For instance, the hydroxyproline-containing peptide L6 is highly homologous to the amino acid region 292-311 ( $P=$ hydroxyproline; $\mathrm{X}=$ amino acid unknown; - = space)

peptide L6: $\quad$ E N $P$ S X $P P X X P$ A $P$ A X T T T S P G X L aa 292-311: E N P S T P P - - P A P A P T P T P P G K L

This fact clearly indicates that the $75 \mathrm{kDa}$ glycoprotein fraction represents a family of closely related polypeptides. $\mathrm{p} 75 \mathrm{~K}$ is representative of this family, as it contains the essence of all the peptide information available.

The deglycosylated polypeptides of the $75 \mathrm{kDa}$ glycoproteins have apparent molecular masses on SDS-PAGE of 65 and $68 \mathrm{kDa}$ respectively. These values are significantly larger than the predicted molecular weight of $46 \mathrm{kDa}$ for $\mathrm{p} 75 \mathrm{~K}$. This discrepancy was resolved by expression of a truncated form of $75 \mathrm{KcDNA}$ encoding amino acid positions 30-442 (the mature polypeptide) in Escherichia coli. This recombinant polypeptide shows the same mobility on SDS-PAGE as the deglycosylated forms of $75 \mathrm{~K} \alpha, 75 \mathrm{~K} \beta$ and $75 \mathrm{~K} \delta$ (data not shown), indicating that the highly acidic polypeptides exhibit irregular electrophoretic mobilities.

\section{Immunological studies}

Polyclonal antisera against the $75 \mathrm{kDa}$ glycoproteins were obtained by immunizing three rabbits with $75 \mathrm{~K} \alpha, 75 \mathrm{~K} \gamma$ and $75 \mathrm{~K} \delta$ respectively. As expected, the antisera crossreact with each of the purified $75 \mathrm{kDa}$ glycoproteins and with all other glycoproteins of the EDTA cell wall extract, as shown by Western blot analysis (Figure 8A, lane 2). This cross-reactivity remains even after HF treatment of the EDTA extract (Figure 8A, lane 3). Therefore, the polypeptide backbones of all EDTA extractable cell wall glycoproteins share similar epitopes, again confirming the existence of a protein family. Unfortunately, the high degree of cross-reactivity among these glycoprotein species excluded studies to localize individual species in the cell wall.

The antisera raised against the $75 \mathrm{kDa}$ glycoproteins of 


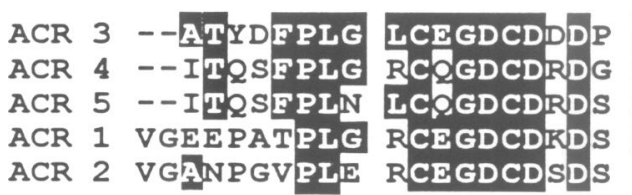

ACR 3 --ATYDFPIG LCFGDCDDDP
ACR 4 --ITQSFPLG RCOGDCDRDG
ACR 5 --ITSSEPIN LCDGDCDRDS
ACR 1 VGEEPATPLG RCEGDCDRDS
ACR 2 VGANPGVPIE RCEGDCDSDS
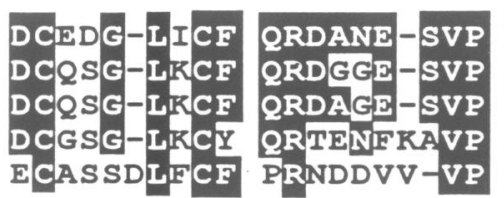

GCSGGSSDGS GCSGGSSDHS GCSGGSSDHS GCSGGAQDDS GCRGGOSDDS

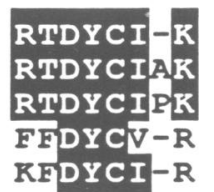

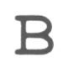

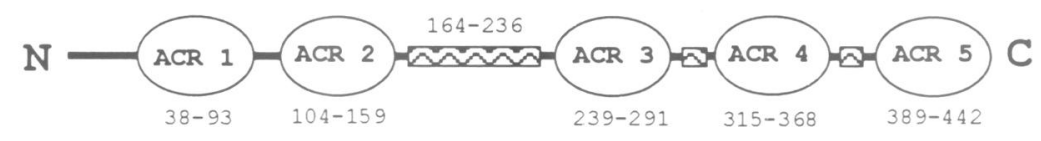

Fig. 7. Structure of the $75 \mathrm{KcDNA}$-encoded polypeptide. (A) Alignment and comparison of the ACR domains. Only identities with the central domain (ACR 3, top line) are shown. (B) Schematic representation of the polypeptide structure. Hatched boxes indicate the polyproline streches. Amino acid positions of the polypeptide segments are specified.

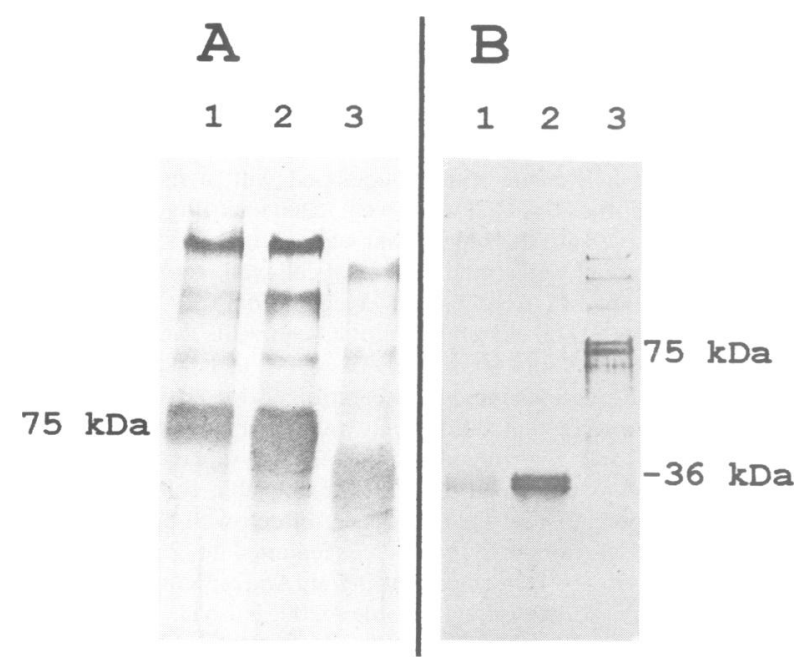

Fig. 8. Western blot analysis. (A) A 1:1000 dilution of the antiserum raised against $75 \mathrm{~K} \gamma$ was used. Lane 1 , whole cell lysate of C.fusiformis (10 $\mu \mathrm{g}$ protein); lane 2, EDTA cell wall extract of C.fusiformis ( $1 \mu \mathrm{g}$ protein); lane 3, HF-treated EDTA cell wall extract of $C$.fusiformis (1 $\mu \mathrm{g}$ protein). 8\% SDS-PAGE. (B) A 1:200 dilution of the antiserum raised against $75 \mathrm{~K} \gamma$ was used. Lane 1 , whole cell lysate of N.pelliculosa $(10 \mu \mathrm{g}$ protein); lane 2 , EDTA cell wall extract of N.pelliculosa $(0.5 \mu \mathrm{g}$ protein); lane 3, EDTA cell wall extract of C.fusiformis $(0.1 \mu \mathrm{g}$ protein). $10 \%$ SDS-PAGE.

C.fusiformis specifically detect two proteins in an EDTA extract of purified cell walls from the freshwater diatom Navicula pelliculosa (Figure 8B, lane 2). These proteins have an apparent molecular mass of 36 and $34 \mathrm{kDa}$ respectively. A tryptic peptide (Np.1) derived from the purified $36 \mathrm{kDa}$ protein confirms the close relationship to the $75 \mathrm{kDa}$ glycoproteins. Amino acids $1-15$ of this peptide are strikingly homologous $(60 \%$ amino acid sequence identity) to amino acids $345-359$ of p75K.

Np.1 1-15: $\quad$ X G T E S V P G X S G S G S X p75K 344-359: D G G E S V P G C S G G S S D

It is therefore apparent that the $36 \mathrm{kDa}$ cell wall protein of N.pelliculosa is a member of the same protein family.

\section{Discussion}

Sequential extraction of C.fusiformis cell walls reveals two ways in which proteins are incorporated into the valve. One way seems to work in a calcium-dependent manner, since the EDTA-extractable $75 \mathrm{kDa}$ glycoproteins specifically bind calcium. The second way is sensitive to HF treatment and thus may involve intimate association of the proteins with the silica parts of the cell wall. The HF-soluble proteins are putative components of an organic matrix within the silica, as is postulated for the cell wall of the diatom Cyclotella meneghiniana by Swift and Wheeler (1992).

Due to the striking homology of their polypeptides and their immunological similarity, the $75 \mathrm{kDa}$ glycoproteins, as well as the remaining EDTA-extractable cell wall glycoproteins, would seem to be members of a protein family. The occurence of a related protein in the EDTA cell wall extract of the diatom N.pelliculosa indicates that these proteins are general components of diatom cell walls and not species-specific molecules connected to the unique valve architecture of C.fusiformis. In contrast to this diatom, N.pelliculosa possesses a highly silicified cell wall that is much more typical of diatoms. Thus it may be possible that differences in valve architecture of different diatom species are reflected in different biochemical properties of the members of this protein family.

p75K may represent the general structure of the members of this protein family. It appears to be composed of only two structural elements: (i) an ACR domain of $\sim 55 \mathrm{bp}$ in length containing the CE/QGDCD hexapeptide motif and (ii) a polyproline domain of variable length. Both domains may also be present in the primary structures of all members of this protein family, but may vary with regard to repeat number and arrangement. This is suggested by the modular structure of $\mathrm{p} 75 \mathrm{~K}$, as shown in Figure 7B.

A common property of the members of this protein family is their affinity for calcium (see Figure 4B, lane1). We propose that the calcium binding sites reside within the ACR domains. These domains are similar to the EF hand motifs of calmodulin and troponin c (Strynadaka and James, 1989). 
Amino acid position

ACR consensus sequence

15 CEGDCDXDXDCXS

EF hand consensus sequence X D X B X B X X X X X E $(\mathrm{B}=\mathrm{D}$ or $\mathrm{N})$

The N-terminal regions of both consensus sequences contains acidic amino acid residues (mostly aspartate) in every other amino acid position. The amino acid residues at positions 2, 4, 6, 8 and 13 of the EF hand consensus sequence provide oxygen ligands to the $\mathrm{Ca}^{2+}$ ion. The glutamate residue at amino acid position 13 is conserved in all known EF hand motifs. In the ACR consensus sequence this position is occupied by a serine residue. As a consequence, this sequence may not be regarded as an $\mathrm{EF}$ hand motif. Nevertheless, it is plausible to ascribe $\mathrm{Ca}^{2+}$ binding competence to the ACR consensus sequence, since it contains potential oxygen ligands to the $\mathrm{Ca}^{2+}$ ion at the appropriate positions.

A striking feature of $\mathrm{p} 75 \mathrm{~K}$ is the sequence of 29 amino acids preceding the mature polypeptide. We speculate that this pre-sequence is necessary for targetting the $75 \mathrm{kDa}$ glycoproteins to the cell wall. The putative signal sequence encoded by amino acids 1-17 may mediate transfer of the polypeptide into the lumen of the endoplasmatic reticulum. After transport to the Golgi apparatus and glycosylation, the second part of the pre-sequence (amino acids 18-29) may be responsible for sorting the $75 \mathrm{kDa}$ glycoproteins to the SDV, the site of cell wall biogenesis. This model implies that the SDV is connected to the Golgi apparatus via transport vesicles. In order to test the hypothesis of consecutive sorting, we are currently investigating whether the immature $75 \mathrm{kDa}$ glycoproteins are processed in two successive steps in vivo. Although the connection between the Golgi apparatus and SDV has yet to be elucidated, there is evidence that development of the SDV depends on glycosylation events in the endoplasmatic reticulum and Golgi apparatus (Lee and $\mathrm{Li}, 1992$ ).

Interestingly, acidic and calcium binding proteins are known to be involved in the biomineralization of calcified structures, such as the $\mathrm{CaCO}_{3}$ shells of molluscs and foraminifera, as well as teeth and bone, which are made of hydroxyapatite, $\mathrm{Ca}_{5}\left(\mathrm{PO}_{4}\right)_{3} \mathrm{OH}$ (Weiner, 1985). It has been shown that these proteins are potent regulators of crystal growth by inhibiting the crystallization process (Wheeler et al., 1988; Weiner and Addadi, 1991). In contrast to the crystalline structure of calcified tissues, the cell walls of diatoms contain amorphous, hydrated $\mathrm{SiO}_{2}$ and lack $\mathrm{Ca}^{2+}$ as a component of the mineral. In this respect it is astonishing that similar types of molecules, namely calcium binding acidic glycoproteins, are recruited for the formation of the mineralized structure. This similarity may be coincidental and the $75 \mathrm{kDa}$ glycoproteins could serve solely as structural components that are incorporated into the cell wall via calcium bridges. On the other hand, analogously to the function of the proteins in calcified tissues, the $75 \mathrm{kDa}$ glycoproteins could define the molecular constraints for silicate polymerization in the SDV. In this model, silicon could not be deposited at sites where the acidic glycoproteins are located, which would result in a species-specific patterning of the silica structures. Since the $75 \mathrm{kDa}$ glycoproteins, together with the other EDTA-extractable cell wall glycoproteins, precipitate in the presence of $\mathrm{Ca}^{2+}$ in vitro (see Figure $4 \mathrm{C}$, lanes
2 and 5), silica deposition would be inhibited by a macromolecular framework of acidic glycoproteins that are non-covalently cross-linked by calcium bridges.

\section{Materials and methods}

\section{Culture conditions}

An axenic culture of C.fusiformis, kindly provided by B.E.Volcani (Scripps Institute for Oceanography, UCSD, La Jolla, CA), was grown in ASW medium at $20^{\circ} \mathrm{C}$ and 5000-10 000 lux (Darley and Volcani, 1969).

Synchronization of cell wall formation was achieved as follows. Cell cultures $\left(5-7.5 \times 10^{5}\right.$ cells $\left./ \mathrm{ml}\right)$ were successively subjected to a $16 \mathrm{~h}$ dark $/ 6 \mathrm{~h}$ light $/ 16 \mathrm{~h}$ dark rhythm. After the final dark period the cells were centrifuged for $10 \mathrm{~min}$ at $2500 \mathrm{~g}$, washed three times with silicatefree ASW medium (ASW-Si), resuspended in ASW-Si medium to $5 \times 10^{5}$ cells $/ \mathrm{ml}$ and cultured for $24 \mathrm{~h}$ in the light. Silicate was then added to a final concentration of $500 \mu \mathrm{M}$ to initiate cell wall formation.

\section{Purification of the $75 \mathrm{kDa}$ glycoproteins}

Harvested cells (approximately $15 \mathrm{~g}$ wet weight) were washed and resuspended in ten portions of $10 \mathrm{ml} 1 \mathrm{mM} \mathrm{CaCl}$. To each portion about $15 \mathrm{~g}$ glass beads $(0.3 \mathrm{~mm}$ in diameter $)$ were added and cell lysis was achieved by shaking each portion on a Heidolph LAX2000 vortexer at maximum speed for 6 min. Lysed cells were then centrifuged at $600 \mathrm{~g}$ for $5 \mathrm{~min}$. The pellet containing the cell walls was resuspended in $1 \mathrm{mM}$ $\mathrm{CaCl}_{2}$ and centrifuged again at $600 \mathrm{~g}$ for $5 \mathrm{~min}$. This procedure was repeated until the supernatant was colourless. The raw cell walls were pooled, resuspended in four portions of $10 \mathrm{ml} 1 \mathrm{mM} \mathrm{CaCl}_{2}$ and then sonicated using a Branson sonifier equipped with a microtip at half maximum power for $45 \mathrm{~s}$. Cell walls were again centrifuged and washed as described above until the supernatant was colourless. The final pellets consisted of pure cell walls (modification of cell wall preparation method previously described by Coombs and Volcani, 1968).

For preparative EDTA extraction, purified cell walls were resuspended in four portions of $15 \mathrm{ml} 100 \mathrm{mM}$ EDTA, $\mathrm{pH} 8$, and shaken at $4^{\circ} \mathrm{C}$ for 12-24 h. The suspensions were then centrifuged for $10 \mathrm{~min}$ at $3000 \mathrm{~g}$. The supernatants were kept and the cell walls were pooled, resuspended in $50 \mathrm{ml} \mathrm{H} \mathrm{H}_{2} \mathrm{O}$ and centrifuged as above. The supernatants of both centrifugation steps contained the EDTA-extractable cell wall proteins and thus were pooled. The yield was $5 \mathrm{mg}$ of cell wall protein.

The EDTA cell wall extract was concentrated to $2 \mathrm{ml}$ on Diaflo membrane YM 10 (10 kDa cut-off) using an Amicon concentrator. The concentrate was loaded on a Superdex 200 HiLoad 16/60 column (Pharmacia) using $20 \mathrm{mM}$ Tris $-\mathrm{HCl}, \mathrm{pH}, 100 \mathrm{mM} \mathrm{NaCl}$ as the running buffer at a flow rate of $1 \mathrm{ml} / \mathrm{min}$. Fractions containing the $75 \mathrm{kDa}$ glycoproteins were pooled and loaded on a MonoQ HR 5/5 column (Pharmacia) which was equilibrated in $20 \mathrm{mM}$ sodium phosphate, pH 5, (buffer A). After washing the column with more than two column volumes of buffer $\mathrm{A}$, elution was achieved by application of a linear chloride gradient $(0-500 \mathrm{mM} \mathrm{NaCl}$ in buffer $\mathrm{A}$ over $30 \mathrm{~min})$ at a flow rate of $1 \mathrm{ml} / \mathrm{min}$. The $75 \mathrm{kDa}$ glycoproteins elute between 200 and $250 \mathrm{mM} \mathrm{NaCl}(75 \mathrm{~K} \alpha, 200 \mathrm{mM} \mathrm{NaCl} ; 75 \mathrm{~K} \beta, 220 \mathrm{mM} \mathrm{NaCl} ; 75 \mathrm{~K} \gamma$ and $75 \mathrm{~K} \delta, 245 \mathrm{mM} \mathrm{NaCl}$ ). Each $75 \mathrm{kDa}$ glycoprotein fraction was subjected to an individual native PAGE [discontinous electrophoresis according to Laemmli (1970), but without SDS and mercaptoethanol in the buffer]. Each $75 \mathrm{kDa}$ glycoprotein was cut out of the gel and eluted by diffusion into $10 \mathrm{mM}$ Tris $-\mathrm{HCl}, \mathrm{pH} 7.5,1 \mathrm{mM} \mathrm{NaCl}$ buffer. The yield was $5 \mu \mathrm{g}$ $75 \mathrm{~K} \alpha, 100 \mu \mathrm{g} 75 \mathrm{~K} \beta, 100 \mu \mathrm{g} 75 \mathrm{~K} \delta$ and $25 \mu \mathrm{g} 75 \mathrm{~K} \gamma$.

\section{Pulse-labelling}

A normally grown $C$.fusiformis culture $(400 \mathrm{ml})$ was silicon starved as described under culture conditions. At the end of the starvation period the cell density was $5-7.5 \times 10^{5}$ cells $/ \mathrm{ml}$. The culture was then divided into two $200 \mathrm{ml}$ portions. To one portion, $1 \mathrm{ml} 100 \mathrm{mM} \mathrm{Na} 2 \mathrm{SiO}_{3}$ was added ( $+\mathrm{Si}$ cells) and the $\mathrm{pH}$ was quickly adjusted to 7.8 by adding $2 \mathrm{M} \mathrm{HCl}$. No addition was made to the other $200 \mathrm{ml}$ portion ( $-\mathrm{Si}$ cells). At various times, $50 \mathrm{ml}$ aliquots of each portion were removed and washed three times with ASW or ASW-Si medium. Finally, washed cells were resuspended in $1 \mathrm{ml}$ of the corresponding medium, $40 \mu \mathrm{Ci}$ $\mathrm{NaH}^{14} \mathrm{CO}_{3}$ were added to each of the cultures and the cultures were incubated for $2 \mathrm{~h}$ on a shaker at 10000 lux. At the end of the pulse period, cells were washed three times with ASW or ASW-Si medium, harvested and stored at $-20^{\circ} \mathrm{C}$. The preparation of cell walls and EDTA extracts were performed as described above. 


\section{Calcium affinity studies}

Experiments were done with a mixture of all four $75 \mathrm{kDa}$ glycoprotein species. Mobility shift experiments were performed as described in Cartaud et al. (1980). Studies of ${ }^{45} \mathrm{Ca}^{2+}$ binding to $75 \mathrm{kDa}$ glycoproteins blotted onto nitrocellulose membranes were done according to Maruyama et al. (1984)

\section{Sugar analysis}

Synchronized C.fusiformis cells $\left(50 \mathrm{ml}, 5 \times 10^{6}\right.$ cells $\left./ \mathrm{ml}\right)$ were pulselabelled with $0.4 \mathrm{mCi} \mathrm{NaH}{ }^{14} \mathrm{CO}_{3} 6-8 \mathrm{~h}$ after addition of silicate. EDTA extraction of cell walls was performed as described above and the extracts subjected to SDS-PAGE. Radiolabelled $75 \mathrm{kDa}$ glycoproteins were excised from the gel and eluted by diffusion. Neutral sugar composition was determined by radio gas chromatography of the alditol acetates according to Wenzl and Sumper (1981).

\section{Proteolytic digestion and separation of peptides}

An EDTA cell wall extract containing about $100 \mu \mathrm{g} 75 \mathrm{kDa}$ glycoprotein mixture was subjected to SDS-PAGE. The gel was stained with Coomassie blue and destained overnight, the region of $75 \mathrm{kDa}$ was excised and the gel slice was cut into small pieces. Gel pieces were treated as follows: $2 \times 1 \mathrm{~h} 30 \%$ methanol, $7 \%$ acetic acid; $3 \times 1 \mathrm{~h} 50 \%$ methanol, $10 \%$ acetic acid; $2 \times 1$ h $90 \%$ ethanol. Gel pieces were dried in vacuo, subsequently soaked in $1 \mathrm{ml} 10 \mu \mathrm{g}$ trypsin/ml $0.2 \mathrm{M} \mathrm{NH}_{4} \mathrm{HCO}_{3}$ and incubated at $37^{\circ} \mathrm{C}$ overnight. The suspension was centrifuged and the supernatant was kept. After three subsequent washing steps $(2 \times$ $0.2 \mathrm{M} \mathrm{NH}_{4} \mathrm{CO}_{3}, 1 \times 0.2 \mathrm{M} \mathrm{NH}_{4} \mathrm{CO}_{3}, 50 \%$ acetonitrile), the supernatant of the first centrifugation step and the wash eluates were pooled, filtered and dried in vacuo. The lyophilysate containing the peptides was dissolved in $6 \mathrm{M}$ guanidinium hydrochloride and stored until separation was performed.

Seventy-five kDa glycoproteins $75 \mathrm{~K} \beta, 75 \mathrm{~K} \gamma$ and $75 \mathrm{~K} \delta$ ( $50 \mu \mathrm{g}$ each), purified by SDS-PAGE, were separately dissolved in $200 \mu \mathrm{l} 50 \mathrm{mM}$ Tris $-\mathrm{HCl}, \mathrm{pH} 8$, and digested with $2 \mu \mathrm{g}$ endoproteinase $\mathrm{LysC}$ at $37^{\circ} \mathrm{C}$ overnight. Peptides were separated by reversed phase HPLC on a Vydac $218 \mathrm{TP} 5 \mu \mathrm{m}$ column (MZ Analysentechnik, Mainz, Germany) as described by Ertl et al. (1989).

\section{Amplification of $75 K$ cDNA by PCR}

The amino acid sequence information of the peptide AVPGXSGGAQDSSFFDYXVR was used to synthesize the antisense oligonucleotide primer 5'-GTA RTC RAA RAA-3' (corresponding to amino acid sequence FFDY). This primer was used to reverse transcribe RNA. The sense primer 5'-GCN GTN CCN GG-3' (corresponding to amino acid sequence AVPG of the same peptide) was used to amplifiy the resulting cDNA by PCR. Forty cycles of amplification generated a cDNA fragment of $51 \mathrm{bp}$ in length that was cloned into the SmaI site of pUC18 by blunt-end ligation.

RNA was extracted from the diatom cells by the method of Kirk and Kirk (1985). Reverse transcription was performed in a final volume of $20 \mu \mathrm{l}$ containing $50 \mathrm{mM}$ Tris $-\mathrm{HCl}, \mathrm{pH} 8.3,40 \mathrm{mM} \mathrm{KCl}, 6 \mathrm{mM} \mathrm{MgCl}$, $1 \mathrm{mM}$ dithiothreitol, $20 \mathrm{U}$ RNAguard (Pharmacia), $400 \mathrm{pmol}$ antisense oligonucleotide, $1 \mathrm{mM}$ each dNTP, $1 \mu \mathrm{g}$ RNA and $200 \mathrm{U}$ MoMuLV reverse transcriptase. Incubation was at $37^{\circ} \mathrm{C}$ for $60 \mathrm{~min}$. After addition of $80 \mathrm{ml} 1 \times$ PCR buffer containing 1200 pmol sense and $400 \mathrm{pmol}$ antisense oligonucleotide and $2.5 \mathrm{U}$ Taq polymerase, thermal cycling (Perkin-Elmer Cycler 9600) was initiated (40 cycles: denaturation at $94^{\circ} \mathrm{C}$ for $15 \mathrm{~s}$, annealing at $40^{\circ} \mathrm{C}$ for $20 \mathrm{~s}$ and extension at $72^{\circ} \mathrm{C}$ for $5 \mathrm{~s}$ ).

The sequences of the remaining $5^{\prime}$ and $3^{\prime}$ stretches were established by the RACE-PCR technique (Frohman et al., 1988). PCR products were blunt-end ligated into the SmaI site of pUC18 and sequenced. DNA sequencing was performed by the dideoxy method (Sanger et al., 1977) using T7 DNA polymerase (Pharmacia). Synthetic oligonucleotides were used to sequence the cDNA in both directions.

\section{Expression of mature 75K polypeptide in E.coli}

A cDNA fragment encoding the mature $75 \mathrm{~K}$ polypeptide (amino acid positions 30-442) was generated, cloned into the NdeI site of pET1la and expressed in E.coli following the method of Studier et al. (1990).

\section{Acknowledgements}

We wish to thank Dr R.Deutzmann for sequencing peptides. We are indebted to Dr J.Ortiz for critically reading the manuscript. We gratefully acknowledge invaluable support of our work by Prof. B.E.Volcani. In addition, Prof. B.E.Volcani provided us with samples of purified cell wall from C.fusiformis and N.pelliculosa for comparison with our cell wall preparations.

\section{References}

Cartaud,A., Ozon,R., Walsh,M.P., Haiech,J. and Demaille,J.G. (1980) J. Biol. Chem., 255, 9404-9408.

Coombs,J. and Volcani,B.E. (1968) Planta (Berl.), 82, 280-292.

Darley,W.M. and Volcani,B.E. (1969) Exp. Cell Res., 58, 334-342.

Ertl,H., Mengele,R., Wenzl,S., Engel,J. and Sumper,M. (1989) J. Cell Biol., 109, 3493-3501.

Frohman,M.A., Dush,M.K. and Martin,G.R. (1988) Proc. Natl Acad. Sci. USA, 85, 8998-9002.

Hecky,R.E., Mopper,K., Kilham,P. and Degens,T.E. (1973) Mar. Biol., 19, 323-331.

Kirk,M.M. and Kirk,D.L. (1985) Cell, 41, 419-428.

Laemmli,U.K. (1970) Nature, 227, 680-685.

Lee,M. and Li,C.W. (1992) Bot. Bull. Acad. Sin., 33, 317-325.

Maruyama,K., Mikawa,T. and Ebashi,S. (1984) J. Biochem., 95, 511-519.

Mort,A.J. and Lamport,D.T.A. (1977) Anal. Biochem., 82, 289-309.

Paul,J.S. and Volcani,B.E. (1976) Arch. Microbiol, 110, 247-252.

Perlman,D. and Halvorsson,H.O. (1983) J. Mol. Biol., 167, 391-409.

Reimann,B.E.F., Lewin,J.C. and Volcani,B.E. (1965) J. Cell Biol., 24, 39-55.

Sanger,F.S., Nicklein,S. and Coulson,A.R. (1977) Proc. Natl Acad. Sci. USA, 74, 5463-5467.

Showalter,A.M. (1993) Plant Cell, 5, 9-23.

Studier,F.W., Rosenberg,A.H., Dunn,J.J. and Dubendorff,J.W. (1990) Methods Enzymol., 185, 60-89.

Strynadaka,N.C.J. and James,M.G.N. (1989) Annu. Rev. Biochem., 58, 951-998.

Swift,D.M. and Wheeler,A.P. (1992) J. Phvcol., 28, 202-209.

Volcani,B.E. (1978) In Bendz,G. and Lindquist,I. (eds), Biochemistry of Silicon and Related Problems. Plenum Publishing, New York, NY, pp.177-204.

Volcani,B.E. (1981) In Simpson,T.L. and Volcani,B.E. (eds), Silicon and Siliceous Structures in Biological Systems. Springer-Verlag, Berlin, Germany, pp. 157-200.

Weiner,S. (1985) CRC Crit. Rev. Biochem., 20, 365-408,

Weiner,S. and Addadi L. (1991) Trends Biochem. Sci., 16, 252-256.

Wenzl,S. and Sumper,M. (1981) Proc. Natl Acad. Sci. USA,78, 37163720.

Wheeler,A.P. Rusenko,K.W., Swift,D.M. and Sikes,C.S. (1988) Mar. Biol., 98, 71-80.

Received on May 30, 1994; revised on July 14, 1994 